\title{
Legal biography, oral history and the Cambridge Eminent Scholars Archive ${ }^{1}$. By \\ Lesley Dingle
}

\begin{abstract}
ESA is a digital archive based on interviews with prominent personalities associated with the Law Faculty of Cambridge University. It constitutes a unique repository of audio, textural and photographic materials, providing insights into the careers of scholars, jurists and practitioners. Motivations for the establishment of the archive in 2005 were: recording reminiscences of scholars back to WWII and its immediate aftermath; documenting developments in administration and teaching in the Faculty and colleges; archiving voices of scholars taking about their early lives, careers and published works; compiling a crossindexed reference of personalities mentioned in interviews; and generating an awareness amongst students and younger staff of the rich heritage of the Faculty. The methodology and strategy of conducting interviews and compiling entries is briefly described. Finally, in the broader context of legal biography, it is argued that such oral histories are an essential component because they capture aspects of personality that written accounts cannot and thereby reveal traits that conventional biographies may miss. This claim is illustrated by selected examples from the archive, that currently contains twenty interviewees.
\end{abstract}

\section{Introduction}

To Peter Brophy, in his assessment of the future role of libraries, the Information Universe encompassed "the sum totality of all information sources available throughout the world, in whatever format” (2007 p. 164). He argued that in the digital age, libraries must switch from collecting physical artifacts that reflect this totality, to becoming intermediaries which provide users with access to remote sources. In the process, the interests of libraries will have to be reassessed, presenting the opportunity (and desirability) to create centres that hold unique local resources, the digital components of which can also be made available, nationally and internationally (Brophy 2007 p. 179-180) ${ }^{2}$.

It is the development of such an archive, and its relevance to the debate on the significance of legal biography (particularly oral history) in contributing to an understanding of legal history, that I wish to outline here.

\section{Original Motivation for developing the Eminent Scholars Archive}

The Law Faculty has been in existence at Cambridge University since the Middle Ages, and details of its colourful history have been summarised, inter alia, by Baker (1996), while biographies of prominent Cambridge legal figures have appeared from time to time (e.g. W. Whewell - Fisch \& Schaffer, 1991: F. W. Maitland - G. R. Elton, 1985). However, to my knowledge there has been no attempt to collate an archive of biographic information from a spectrum of scholars over a particular time frame within the Faculty.

In the latter half of the twentieth century, Cambridge University Law Faculty acquired a reputation for scholarship and teaching that few institutions can rival, and over the decades

\footnotetext{
${ }^{1}$ http://www.squire.law.cam.ac.uk/eminent_scholars/

2 It should be remembered that Brophy was looking at libraries in general, not specifically law libraries. In fact, he did not mention the latter in his book.
} 
many of its luminaries established international legal reputations, as well leading colourful and interesting lives. Sadly, with the inexorable passage of time memories fade, and eventually those of us outside the window of personal experience are left only with their written works and second-hand impressions. Consequently, these personal histories vanish, and with them irreplaceable, esoteric aspects of the Faculty's legacy. Also, there is no record of these scholars' voices.

I became aware of the richness of this ephemeral resource during the nine years I shared a room with the remarkable nonagenarian, the late Emeritus Professor Kurt Lipstein (1909-2006). He was a fund of reminiscences that extended to his pre-WWII native Germany, and listening to his conversations with a fellow refugee (the late W. A. F. P. "Willi" Steiner from Vienna) was both fascinating and informative. ${ }^{3}$ This determined me to capture and preserve for posterity memories and anecdotes Professor Lipstein had accumulated over a seventy year association with the Faculty and the Squire Law Library. In particular, he was the only living Faculty member to have worked in all three of the library's manifestations: Downing Street (1934-37), the Old Schools (1937-95) and West Road (19952006).

My interviews with Professor Kurt Lipstein took place in April/May 2005, and I immediately recognised how valuable his reminiscences, recounted in his own voice, were, when used, for instance, to complement his contribution to a volume such as Jurists Uprooted (Beatson \& Zimmerman 2004). The Faculty was greatly saddened by Kurt's death in late 2006, but his demise only served to emphasise the importance of much of the information that such eminent scholars hold. It also demonstrated that biographic details could be so illuminating of someone's legal outlook. In addition, Professor Lipstein donated photos for the archive, and I constructed a bibliography of his scholarly works and a short biographic summary, which was later published (Dingle \& Bates 2007). Similarly, I realised that although the published works of other luminaries in the Faculty were available, detail of the backgrounds to their careers was not, and I began to consider further interviewees. In particular, I was aware of the rapidly reducing number of Cambridge scholars with memories of WWII or its immediate affects. This had been a unique time in the Faculty's development, which included returning warriors, weekenders, changing curricula, and the admission of women to colleges, and it needed to be captured, along with the later machinations of the Faculty's move from central town to its present site. Documenting what remains of this collective memory for the Faculty, and the resulting interviews and tributes became the aim of the Eminent Scholars Archive (ESA).

To achieve this in a digital environment required more than just a recorder and note book, and I was fortunate to have two colleagues who also shared my vision, and were keen to further the project. Daniel Bates ${ }^{4}$, formerly a practicing solicitor, was able to edit and archive the audio records and present these and the textural and photographic material, while Matt Martin ${ }^{5}$ was the Faculty's website designer. We three launched the ESA in September 2006 with Kurt Lipstein's tribute. Sadly Kurt died three months later, so prophetically, we had achieved our first aim.

${ }^{3}$ I regret not having interviewed this contemporary and fellow refugee from pre-War anti-Jewish discrimination, who later worked at the Institute of Advanced Legal Studies, and Squire Law Library. W. A. F. P. Steiner (1918-2003).

${ }^{4}$ Freshfields Legal IT Teaching and Development Officer, Faculty of Law, Cambridge University

${ }^{5}$ Currently working in British Columbia. 
Coincidently at this time I reviewed Brophy's book The Library in the Twenty-first Century (Dingle 2008), and realised that the oral history archive which we were building, would become a unique resource of the type envisaged by Brophy in realigning the role of libraries. ESA would have potential interest for both local and international audiences, and at the very least would appeal to the large world-wide diaspora of Cambridge law faculty students. It would also hold data for scholars researching our interviewees in order to understand their views on particular legal issues.

Recently, Raisch (2011, p. 277), in her overview of electronic collections in foreign, comparative and international law, has echoed Brophy's sentiments on the relevance of customised databases, by mentioning ESA as an example of a repository of "archive[d] materials of general historic or public interest....residing at [an] institution and linked from the home page".

At the bare minimum, ESA provides a record of the voices of scholars, a précis of their careers told in their own words, and a plethora of detail, from various standpoints, of the evolution of the Law Faculty during the second half of the twentieth century. Taken in conjunction with scholars' legal writings and viewpoints, these biographical expositions can reveal much about the underlying causes for the stances they adopted: the scholastic equivalents to the inarticulate premises that may attend judicial pronouncements. I shall return to this issue once I have outlined details of the methodology.

\section{Methodology}

Numerous methodologies in conducting oral history interviews can be found covering a wide variety of topics, and the advice they give ranges from simple common sense to, from a UK standpoint, legally complex and highly regulated procedures ${ }^{6}$. Further advice comes in the text by Neuenschwander (2009) which is 167 pages of extolling legal niceties for interviewers on copyright, being sued for defamation, various contractual pitfalls, and so forth. Luckily, the latter is written for the US market, and a review for the Oral History Society (MacQueen 2010) stresses UK researchers to "treat the detail [therein] with care and caution". I would advise them to consult the practical steps given on the website of the Oral History Society of the UK ${ }^{7}$.

As previously mentioned, ESA grew in a relatively informal fashion, but the aims were clear from the outset. These were for scholars to reminiscence on personal aspects of their careers; to record memories that bore on the Faculty and their colleagues; and finally to collect insights into notions and circumstances that surrounded their published works and/or legal decisions. In the course of this I restricted my attention to those with close affinities to

${ }^{6}$ Two typical US examples are: University of California, Santa Barbara Oral History Program Donald C. Davidson Library. Oral History Methodology, the Art of Interviewing http://www.history.ucsb.edu/faculty/marcuse/projects/oralhistory/199xDRussellUCSBOralHi storyWorkshop.pdf; and Indiana University Center for the study of History and Memory http://www.indiana.edu/ cshm/oral_history techniques.pdf

A UK example, from the joint Kingston University and St George's Hospital project http://www.healthcare.ac.uk/research/groups/workforce-development/nurses-lives/oral$\frac{\text { history-methodology/ }}{7}$

${ }^{7}$ http://www.oralhistory.org.uk/ethics.php 
the Faculty, and/or the annual Visiting Goodhart professors. In one instance I have interviewed the wife of a late Cambridge professor and ICJ judge.

The strategy for the creation of an ESA entry consists of three phases - 1. interviews; 2. preparation of transcripts and collation of other digital materials; and 3. public website presentation, including a permanent electronic archive, as well as sundry non-digital items relating to individual scholars.

During the first phase, interviews take place over several sessions (typically each an hour long), either in the Faculty or at the scholar's home, and are recorded using two digital devices in MP3 format (one as back up). Interviews are typically a few weeks apart, but vary depending on the subject's commitments. This phase can be time consuming because it invariably entails considerable background research by myself on the subject's career and scholastic production, followed by the submission to the scholar of a list of topics that may be covered in each interview (not specific questions). Experience has taught me that if the interviewees are aware of the topics before each session, they are more relaxed and less wary of being "ambushed", in a journalistic sense. This makes for a more convivial atmosphere, and a conversational style. Although most scholars are used to public speaking, these interviews are not the same as lecturing. Putting interviewees at ease is a very important consideration.

One aspect that has been paramount to the success in persuading scholars to participate in the project has been the building of trust to overcome initial reticence. I believe this has been achieved, at least partly, by their participating in a Squire Law Library/Faculty project, and the fact that there are no commercial "hidden agendas". I make it clear from the outset that the fruits of our collaboration will be made public on the Library's website, and that I will distil the interview/s into a biographic summary. I do this by showing prospective interviewees print-outs and/or examples of previous scholars' web pages. Of course, this was less easy in the initial stages, when the ESA had fewer entries.

I usually follow a chronological progression of a scholar's career over the course of the interviews, starting with their early life and education, and concentrate on their scholarly works in the later interviews.

The second phase starts with the production of typescripts from the oral records which are transmitted to a professional agency. The resulting transcripts invariably require some editing ("ums", "ahs" and trivial comments), and annotating and insertion of explanatory notes. At this stage, each question put by the interviewer is given a unique running number that carries across the series of interviews for each scholar, and allows rapid location of items of interest by listeners, researchers, or as a cross-reference with any publications that result from the archive data.

A particularly important factor in establishing the trust mentioned above is an assurance that my scholars will be shown a copy of the transcripts, with the implication that they can make minor editorial changes where mistakes have crept in (although altering the oral record is not possible, except in deleting items such as telephone calls, intrusions by third parties etc). In this I diverge from what many fellow oral history archivists see as best practice. For example, the George Washington University Law School Oral History Project states that "words of the interviewer and narrator are not deleted or altered in any way, nor is their order changed. Any material alteration would destroy the integrity of the interview as a 
history source..."” (my italics).

Similarly, Oldfather (2010 p. 854) queries whether the interviewee "should be provided with the opportunity to review the transcript", even if this is only to correct factual errors or misstatements, "we would be justified in placing somewhat more faith in statements in a transcript that the interviewee did not have a chance to review".

At a general level, one cannot argue with these sentiments, and I have certainly been very circumspect in any such editing. I cannot recall any "material” alterations, but like many things in law, semantics may come into play here. In the end, though, my experience has been that unless an undertaking of review of the transcript had been given, some at least of the interviews in ESA would never have taken place, and the voice and reminiscences of these eminent scholars would have been lost forever. I have done my best to strike a reasonable compromise, in the interests of preserving the oral history of certain scholars.

In the third phase, the oral record and transcripts are placed on the Squire Law Library Eminent Scholars Archive website, along with a variety of background information. The latter include a summary biography, a bibliography of the scholars published works (I invite them to submit a list, which I may supplement), lists of significant cases in which they may have been involved, annotated photographs provided by the scholars (to record their childhood, early career and memorable occasions etc), as well as images taken contemporaneously with the interviews. For those subsequently-deceased scholars, obituaries may also be posted (with the compilers' consent).

Also, I construct a progressively expanding cross-referenced listing of all personalities mentioned during the course of the combined ESA transcripts - a cumulative memory index. The point of reference is the question number (Q) in which mention is made in any particular interview. Many of the personalities in the index will also occur in a database of Faculty members that I have constructed from the Cambridge University Reporter back to the 1930s. I use this to remind scholars of personalities who might have crossed their paths during their undergraduate or Faculty days. (There may be some scope for prosopographical work on the Faculty when the index is large enough). Finally, the digital records are placed in the University of Cambridge D-Space digital repository, and the audio records are made available via i-tunes on the Faculty video-streaming facility.

For the technical work in this third phase, my colleague Daniel Bates does the audio editing, and website insertion and formatting, as well as photography during interviews. The original website was designed by our mutual colleague Matt Martin, who has subsequently left the Faculty. We have also had the services of the University Library Imaging Services (Mr Don Manning) who scanned many of the original historic photographs in the early years of the Archive.

There is an amount of physical, non-digitised material (e.g. older books, and papers) relating to scholars that are kept in the Squire Library. These have been donated, and are available for research scrutiny on request ${ }^{9}$. Finally, and with the scholar's consent, certain aspects of their career that have been highlighted by the interviews, may be the subject of

\footnotetext{
${ }^{8}$ Jennie Meade (2012) p. 15.
}

www.law.gwu.edu/Library/Friends/Documents/Legal_Miscellanea/FriendsNwslttr_S12.pdf

${ }^{9}$ The most extensive is a collection of Professor Lipstein's papers, a catalogue of which can be seen on the Janus Archive - http://janus.lib.cam.ac.uk/ 
further publications ${ }^{10}$.

\section{Value of Legal Biography and Oral History in legal scholarship}

A perusal of some recent literature assessing legal biography as a genre reveals various levels of scepticism amongst legal historians and scholars as to its intellectual value (e.g. McEldowney 2004, Prest 2011). In one study, the author addresses the issue head on and asks whether "legal biography [is] really legal scholarship" (Parry 2010). He concluded that there is "scant trace of even modest enthusiasm towards legal biography as a form of scholarly enquiry with most university law schools"......."Legal scholars do not do biography, it seems"11, and that to some legal academics, legal biography is "an unmentionable activity"12. Reinforcing this attitude, Prest (2011, p. 186), described what he calls the "jaundiced....stance of many practising historians", citing the editors of a recent (2009) American Historical Review symposium on historians and biography that the journal "almost never publish[es] articles of a biographical nature" ${ }^{\text {"13 }}$.

The reasons for the rejection by some legal scholars of the importance of biographical data are varied. Parry (2010) summarises these, and draws a general conclusion that it is partly due to the large number of biographies on the subject of legal practitioners, in which the narrative has sometimes been presented in "dramatic, even sensational language". This tarnishes them as bona fide scholarship. It is a perception highlighted by Prest (2011, p. 186) who again cites the editors of the American Historical Review (2009) as having a "reserve verging on the disdain”. Despite Prest's own positive attitude towards legal or judicial biography, he says the genre has a "fatal preference for sensational and ultimately trivial narrative over complex or reflective analysis".

Similar degrees of scepticism and/or dismissiveness, particularly, towards the oral history elements of biography, were earlier rife in social and historical circles. Grele (2006, p. 65) citing Tilly (1985: “ahistorial and unsystematic”) and Thompson (2011, p. 79) citing O'Farrell (1979: equating oral history with myth, not history) are two examples given in recent overviews of the development of the subject.

Despite such critical attitudes in legal circles, Parry (2010, p. 215) deduces that the extraction of empirical facts by legal biographers can provide "insightful and important explanations of historical events” even if the narrative may appear descriptive and lacking in scholarly weight. He draws a distinction between this empirical approach and what he calls the pursuit of an "intellectual alternative", in which the biographer is preoccupied with the subject's ideas. The tension he sees between these two approaches is primarily caused by the empirical approach playing into what he characterises as a Victorian view, in which history is strongly influenced by leading actors ${ }^{14}$. This contrasts with the modern perception that sees social phenomena (rather than personalities) driving historical events, which in the twentieth century led to "the demise of the biography as a form of serious scholarship"15.

${ }^{10}$ E.g. Milsom: (2012) 12, LIM 307 - 316. Schwebel: (2011) 11 LIM 55 - 64. Hepple Part II: (2009) 9 LIM 299 - 307. Hepple Part I: (2009) 9 LIM 134 - 140.

${ }^{11}$ Parry (2010) p. 208.

12 Parry (2010) p. 210.

13 (2009) 114 American Historical Review p. xiv.

${ }^{14}$ Parry (2010) p. 220.

${ }^{15}$ Parry (2010) p. 223. 
This state of affairs is odd, not to say hypocritical, if one accepts, empirically, that law is an artificial construct, and that its study has to be, at heart, an exercise in subjectivity. Seeing, in the context of English law since mediaeval times, that we are dealing with an edifice built by a numberless multitude of philosophers, academics, jurists, clerics, politicians, and (most recently) bureaucrats, whose abilities will have ranged from inspired to incompetent, any knowledge of the motivation and background of those involved can only but help understand their decisions, attitudes and motivations. As Parry (2010 p. 224) comments "legal biography injects a heavy dose of realism into legal scholarship", echoing a sentiment expressed earlier by McEldowney (2004, p. 219) who saw legal biography as a "means of discovering the sources of legal history and through them of understanding how the laws, customs and norms of society developed". This is particularly so in the common law, which can be "so dependent on individual judgment for its development"16.

Some legal historians have acknowledged the role of personalities in the development of the law in both its "internal” and "external” legal history modes (e.g. Ibbetson 2003). In the former, the predominant practitioners are trained lawyers, and the sources mainly statutes and decided cases ${ }^{17}$, while the latter deal with law in its broadest social, economic and political contexts ${ }^{18}$. In both fields, a thorough understanding of the history and significance of legal developments will be dependent upon the roles individuals or groups have played, as well as the institutions in which they functioned. This brings to bear both biographical and prosopographical data, revealing that the law is not "aloof from the rest of life, but [is] something locked in to society’s culture"19. Parry (2010 p.228) partly attributes the "troubled relationship between legal biography and legal scholarship" to a "disciplinary schism" between these internal and external traditions of legal historical scholarship.

Encouragingly, Parry (2010) sees some green shoots amidst the "awkwardness if not unease" of academics who fear being labelled as legal biographers ${ }^{20}$, and concludes his survey with the plea that "by engaging in a detailed study of the personal development of individuals who have shaped the law it is possible to understand more fully their contribution to the course of legal development”. It is Parry's conclusion that legal scholars can only benefit by engaging with legal biographers (2010 p. 229). There are now several highly regarded academic projects that are archiving such data ${ }^{21}$.

This general optimism has long been accepted in the originally sceptical social and historical circles referred to earlier, where, for example, numerous articles sing its praises in recent handbooks on the subject: Handbook of Oral History (Charlton et el 2006) and The Oxford Handbook of Oral History (Ritchie 2011). As Ritchie (2011, p. 3) summarises "Long

${ }^{16}$ McEldowney (2004) p. 242.

${ }^{17}$ Ibbetson (2003) p. 874.

${ }^{18}$ Ibbetson (2003) p. 875-6, and the amusing and perceptive case analyses of Simpson 1995.

${ }^{19}$ Ibbetson (2003) p. 878.

${ }^{20}$ E.g. Parry (2010) p. 209.

21 "Legal Biography Project” at the London School of Economics (http://www.lse.ac.uk/collections/law/projects/legalbiog/lbp.htm), and "Women’s Legal History Biography Project” at Stanford University (http://wlh.law.stanford.edu/). I can also add the "The Women's Oral History Project” at Columbia Law School (http://www.law.columbia.edu/law_school/communications/reports/Fall2002/portraits1_10), 
before the practice acquired a name...historians conducted interviews to gain insight into great events....”, while Thomson (2011 p. 107) concludes “autobiographic memory....provides the means through which historians can test grand narratives..”

\section{Importance of Oral History within Legal Biography: examples from ESA}

My experience with ESA leads me to suggest that a full appreciation of the contribution to legal scholarship by any individual can be assessed only by analysing their legal production, as well as, and in the light of, biographical details (i.e. their personal and career circumstances).

In other words without biographical detail, the picture is incomplete, and rather than being a potentially embarrassing encumbrance for some legal scholars, legal biography is an essential part of the equation in evaluating any individual's contribution to the evolution of the law. Here I offer experiences with the ESA to illustrate this notion, and give some examples that have forcibly struck me of the possible outcomes of the legal scholarship of an individual, and of the strong element of contingency that runs through the lives of so many of my interviewees. All these factors are subjective (as is the law, as a concept), and to make legal biographies as comprehensive as possible, they should include both written and oral material, if the latter is available. Consequently, I believe biographical detail comprises both written and oral history. In summary, ESA has showed me that the quality of the biographic element can be greatly enhanced by information gleaned from oral sources.

Quality of oral data is an issue addressed by Oldfather (2010), who considers some of the specific drawbacks to oral history, including the generation of undue numbers of anecdotes, memory bias, general subjectivity, as well as the unavoidable danger of the interviewer's interests and biases affecting the answers ${ }^{22}$. These drawbacks have to be set against what I found to be the uniqueness of available insights into important aspects of the careers and publications of the interviewees. These, complete with nuances of delivery, can be captured only by listening to their own voices and modes of expression.

The question is, how important in any particular Legal Biography is the Oral History component? I have selected four examples from ESA that show it can be very important in biographical detail. So important, that without it, much "textural data" in the biography would be missed, flawing the overall assessment of their contribution to legal scholarship. Perhaps one can use the fanciful analogue of feeling the texture of a rich fabric, in contrast to just seeing it.

Judge Stephen Schwebel ${ }^{23}$ had a long and eventful career in international arbitration, as a legal advisor in the US State Department, as an academic teacher, and in the ICJ. He is a lawyer who has seen the workings of international law from all aspects, but being American, has a particular fascination for UK readers: seeing us as others see us.

His scholarly writings on major UN and ICJ issues, have received excellent reviews ${ }^{24}$

22 Oldfather (2010) p. 852-853.

${ }^{23}$ Stephen Myron Schwebel (1929- )

http://www.squire.law.cam.ac.uk/Media/Eminent\%20Scholars\%20Archive\%20

Transcripts/schwebel_transcript_may_2009.pdf

${ }^{24}$ E.g. International Arbitration: Three Salient Problems , Cambridge: Grotius Publications Limited (1987); Justice in International Law: Selected Writings of Judge Stephen M. Schwebel, CUP (1994). 
together with his ICJ judgments. Without biographic information this would be the main evidence upon which scholars would base their assessment of his contribution to international law. However, two outstanding strands embedded in his ESA interview reveal insights, without which the analysis would be flawed.

The first is his lifelong fascination with, and endearment to, the United Nations as an organisation. It started with his preoccupation with the progress of WWII because of his brother's involvement in the US Army, and blossomed with his founding The United Nations Council of Harvard, a student group that promoted the ideals and proceedings of the fledgling organization. Ultimately, it brought him into close personal contact with first UN Secretary General and his family, Trygve Halvdan $\mathrm{Lie}^{25}$, about whom the young law student wrote his Harvard honours thesis ${ }^{26}$. A critical aspect here is that despite the USA's disenchantment with the UN in the 1960s over Soviet and French obfuscation relating to their dues, that continues to the present, Stephen Schwebel had "remained very interested in, and broadly speaking a supporter of the United Nations to this day". The significance of this is that in the late 40s "it's hard to imagine indeed today how prominent a place in American public perception and discourse the United Nations had. The "New York Times", our by far finest newspaper - some treated it as virtually a house organ of the UN, it ran so much everyday about the United Nations.” These oral records are of one who lived through and was deeply involved in the evolution of the UN in its defining years from idealistic foundations to the politicized body of today (on which my next example, Professor Allot has much to say, again from personal experience).

The second strand that runs through Judge Schwebel's interviews is the deep, almost spiritual, debt he holds for the guidance and inspiration of Hersch Lauterpacht ${ }^{27}$ during a brief stay at Trinity College in 1950-51. Notwithstanding the deprivations of college life in immediate post-war England, Stephen Schwebel developed a profound admiration for Professor Lauterpacht, who “....was widely regarded as the leading public international lawyer in the world at that time...... learned a great deal from him and remained very close to him until his death, and he showered me with countless kindnesses. And second, he very shrewdly perceived that at the outset I needed close and good mentoring and he selected his son Eli ${ }^{28}$ to be my tutor, and I was Eli's first tutee". This relatively short experience into an alien scholastic milieu made Judge Schwebel a great Cambridge-phile, if not Anglophile.

The importance of these two facets is more greatly appreciated by the manner of their telling, and legal historians will have a better sense of how they influenced him as a young man. Consequently, such an oral record cannot be ignored in appreciating fully Judge Stephen Schwebel's career achievements in, and contributions to, international law.

A second example is also from international law, and shows a contrasting juxtaposition of events early in a scholar's career. Professor Philip Allott ${ }^{29}$ is held in high

${ }^{25}$ (1896 - 1968). Norwegian politician, Secretary - General of the UN 1946 - 52.

${ }^{26}$ The Secretary - General of the United Nations: His Political Powers and Practice, Harvard, University Press (1952).

${ }^{27}$ Professor Sir Hersch Lauterpacht (1897-1960), Whewell Professor of International Law, University of Cambridge 1938-55, Judge and President of the ICJ until his sudden death.

${ }^{28}$ Emeritus Professor Sir Elihu Lauterpacht, (1928- )

${ }^{29}$ Philip J Allott, Emeritus Professor of International Public Law, (1937-) http://www.squire.law.cam.ac.uk/eminent_scholars/professor_pj_allott.php 
esteem as a philosopher and progressive thinker on the nature and long-term trajectory of international law, although his views are unconventional. He set them out in Eunomia, New Order for a New World, after an eventful career in the UK Foreign Office, and a decade and a half of legal meditation in Trinity College. He admits it is a "very peculiar book". In our interviews Professor Allott talked about his radical ideas, and this record is of immense interest to legal scholars and historians. Hearing his clear enunciation of the antecedents of two of his grand themes to particular events in his career, and discovering their sources, is of great value. It stirs the listener's imagination far beyond mere reading of the transcript, as they are words that could precipitate a revolution of the mind, which is at the core of Allott's career message.

The overriding impression of reading his works and listening to his interviews is his detestation of war and the turmoil, suffering and legal disorder it brings. His views spring from the end of WWII, when, as an eight year old boy, he saw newspaper accounts of the Belsen concentration camp, and shortly after, the horrors of the Hiroshima atomic bomb. These were compounded by a youthful sense of injustice of the Nuremberg war crimes trials. Barely ten years later, these impressions crystallised during one undergraduate seminar at Trinity when he realised that the 1956 Soviet invasion of Hungary was justified on the basis of a letter of "invitation” from the General Secretary of the Hungarian Socialist Workers' Party $^{30}$. As Professor Allott put it, the legalising of war through a set of laws is a repugnant concept, and the incident turned him away from conventional concepts of international relations for life. Such verbal images reinforce his oft repeated description of international politics as "madness". As he put it to me, "living within a reality which is unreal, dangerous, undesirable in the long term, and I think the human race, particularly in the $20^{\text {th }}$ century, did go mad. The human race became a danger to itself because it was living in a reality which could only lead to self harming and self destruction, which is, using the crude word, "mad"."

An extension of his notion of the unsustainability of international law as a concept detached from domestic law provided a paradox between Professor Allott's love of European culture and diversity, and his rejection of the current trajectory of the European project of federalisation and central control. Consequently, the European Union and its fundamentally undemocratic structure is another bette noire. The root of this lay towards the end of his career in the Foreign Office, when he was a member of the team helping draft legislation to be the vehicle by which Prime Minister Edward Heath sold the original notion to the British Parliament in 1972. Philip Allott recounts how he was so disturbed by the deception being perpetrated, that he wrestled with his conscience over resigning. That he didn't, allowed him several more months additional access in the corridors of Brussels to discover further routine deficiencies, there being no culture of parliamentary accountability on the continent. Hearing these first hand from a contemporary observer adds so greatly to their weight. The recording is historical in its own right.

A third example deals with the discovery of aspects of the modus operandi of the scholar being interviewed. Professor "Toby" Milsom ${ }^{31}$ is a legal historian who spent practically his whole career questioning the foundations of his legal speciality, the mediaeval

30 János Kádár (1912 - 1989).

${ }^{31}$ Emeritus Professor Stroud Francis Charles (Toby) Milsom, (1923-). http://www.squire.law.cam.ac.uk/eminent_scholars/professor_toby_milsom.php 
origins of the common law, as expounded by the then undisputed authority F. W. Maitland ${ }^{32}$. Professor Milsom has been described as the "dominant intellectual voice in English Legal historiography" for the last fifty years by one of his contemporaries ${ }^{33}$, and during my interviews with him, I was able to glimpse the sources of some of his hallmark traits: a forensic style, pragmatism, propensity to work alone, self-deprecation and an irrepressible sense of "fun".

To deal with the last item first. The whole interview is infused with Professor Milsom's wry humour and charismatic laughter, ironic considering his poor health, but throughout the ESA, other scholars who knew him as a younger man, have referred to it and his constant reference to the fun of life. To have captured this ephemeral characteristic is a priceless icon.

Toby's very survival, allowing him to enter Cambridge, may well have hinged on an accident he suffered to his head when a youth. He recounted this with touching candour, and the wound rendered him unfit for active military service when war broke out (he was 16 in 1939 - his brother was killed in action early on). The injury also affected his schooling, and although science was his first love, he was barred from the science Tripos when he arrived at Trinity in 1941 on the grounds of inadequate mathematics. Law was only his third choice and by his admission (to me, and in his publications), science remained his true interest. Significantly, his meticulous, forensic, scientific approach to legal research ideally suited him for decades of careful analyses of plea rolls in search of evidence to prove that the then conventional wisdom according to F. W. Maitland ${ }^{34}$ was flawed. Hearing Milsom's account of this lifetime's work, recounted in his own words and punctuated with his hallmark laughter, captures what his contemporaries would have known as a parallel track to his dense erudite publications, but which would have been completely lost to later generations. This aspect of his personality he brushed aside with characteristic self-deprecation that may be rooted in the boyhood dreams of science he never truly abandoned. Now it is preserved for posterity.

Finally, there was his propensity for working alone. By his own admission he had no close colleagues when at LSE (for two stints), and at Cambridge rarely worked at, or depended upon his college (St John's). Where did this arise? Perhaps his isolation when injured, but also there are hints in his interview about his very close affinity with his wife ${ }^{35}$. Toby left Trinity in 1955, coincident with his marrying Irène, the first wife of Leon Radzinowicz ${ }^{36}$, who had moved up to Cambridge in 1948. There followed a very brief interlude at $\mathrm{LSE}^{37}$, before Toby acquired a post at New College Oxford. Toby and his wife were very self-contained, and lived in Greenwich, far from LSE when he obtained his chair in London in 1964. His interviews describe their contentment with life in the suburbs and his leisurely commute on the train. This lifestyle continued when they moved back to Cambridge

${ }^{32}$ Frederic William Maitland (1850-1906) Downing Professor of the Laws of England. His classic History of English Law Before the Time of Edward 1 ( $1^{\text {st }}$ edit 1895).

${ }^{33}$ Ibbetson, (2004).

${ }^{34}$ Maitland was in fact Milsom's hero, the giant of legal history, and Milsom set out to disprove Maitland as a reluctant heretic.

${ }^{35}$ He mentions her twenty-two times in our interviews.

${ }^{36}$ Professor Sir Leon Radzinowicz, (1906-99), Wolfson Professor of Criminology

${ }^{37}$ Incidently, LSE then housing Hermann Mannheim (1889-1974), Radzinowicz's arch enemy in the ongoing battle to establish the first UK institute of criminology, in which the latter prevailed at Cambridge. 
in 1976, and Toby implied that it became more secluded when Irène became seriously ill and needed his presence. Professor Milsom talked candidly about this aspect in his account of the grand celebrations at the centenary of the Selden Society in 1987.

So many of Toby Milsom's traits are captured in the interviews, including his dry wit and humorous delivery, that any assessment of his work can only be enhanced by listening to his self-deprecating style when talking of his intellectual exploits.

Emeritus Professor Bob Hepple ${ }^{38}$ was knighted by HRH Prince of Wales in Buckingham Palace in March 2004. His citation was "for his services to Legal Studies", and amongst the many notices of congratulations there was one from Blackstone Chambers ${ }^{39}$, where he specialises in cases on employment and labour relations law. How did the son of a trade unionist in ethnically-divided, post-WWII South Africa, arrive at this appointment with history, via the Mastership of Clare College Cambridge? The short answer is, by a very circuitous and contingent-strewn route. Sir Bob summed it up in our interviews as "I have been extraordinarily lucky. Whenever things seemed to be going badly one door closes and another one always opens and I have had some very stimulating careers".

Told in his own words, elements that would not be out of place in an adventure novel were revealed. His career had two episodes, and the second, his time in the UK, can be condensed to a compassion for the underdog, and a deep involvement with the legal hazards of labour laws, globalisation, and impingement of bureaucracy on human rights. In contrast, his first legal embodiment can be seen as a harsh apprenticeship amidst the treason trials and state violence of 1960s South Africa, where his own involvement with the banned-ANC precipitated his self-exile in the UK and a new life, anchored in academia. Hearing these revelations in his quiet, very humble tone, immediately conveys the basic humanity of one dedicated to the well-being of others. This is a priceless factor in understanding his legal stance, which is made even more poignant when he describes the history of his family back to the late $19^{\text {th }}$ century. Here, those able to appreciate the niceties of the South African social tapestry, hear how his own background is itself the epitome of the divided nation that he was eventually forced to flee. Seeing it written is one thing, hearing it from him is quite another, and his interviews highlight the social relevances and paradoxes that Bob Hepple's legal journey throws up. Assessing his current reputation is so much easier with the background of his oral history to hand.

These four examples give some particularly apposite illustrations of oral history adding to, and supplementing, more formal legal scholarship in helping assess legal careers, and the way the latter have contributed to the law's direction of travel. All my interviews show elements of this, which leads me to conclude that an oral history component will produce added value to a written biography, including subtle cues analogous to the "inarticulate premise" of judges when deciding issues.

\section{Summary/Conclusions}

ESA is an Internet oral history digital archive of prominent legal scholars associated with the Law Faculty of Cambridge University. It was founded by Lesley Dingle in 2005

${ }^{38}$ Sir Bob Hepple (1934- ), Emeritus Professor of Law, Master of Clare College 19932003. http://www.squire.law.cam.ac.uk/eminent_scholars/professor_sir_bob_hepple.php

${ }^{39}$ Blackstone House, Temple, London, EC4Y 9BW 
with the assistance of Daniel Bates and Matt Martin. So far, twenty scholars ${ }^{40}$ have been interviewed, including the incumbent annual Visiting Goodhart Professor of Legal Science (since 2008). Material available includes audio records, interview transcripts, bibliographies, photographic galleries, and biographic summaries. Much of the data are also stored in the university's permanent online archive: D-Space. Volume of data include 43 hours of audio record and $\sim 500$ photographs.

The aims of the ESA can be summarised. 1 - To capture fast disappearing reminiscences of scholars whose careers extended back to WWII and its immediate aftermath. 2 - To document aspects of the developments in administration and teaching in the Faculty and various colleges in the second half of the $20^{\text {th }}$ century. 3 - To create a local unique archive of the voices of Cambridge eminent scholars talking about their own early lives, careers and published works. 4 - To build a cross-indexed database of reminiscences, anecdotes etc of Faculty personalities, many of whom are deceased. 5 - To generate awareness amongst students and younger staff members of the rich heritage of the Faculty.

Intellectually, the ESA contributes to redefining the future role of the Squire Law Library, as the focus of its resources becomes increasingly electronic and internet-based. ESA is a unique repository that contributes both cultural and scholastic materials to local, regional and international "readers", wherein the Squire Law Library acts as an intermediary, as envisaged by Brophy (2007). In addition, instances encountered in ESA illustrate that legal biography, and specifically oral history, can play a vital role in legal historical studies by providing insights into the philosophy and motivation of scholars, bureaucrats and practitioners who influence the formulation, application and elucidation of the law (in its broadest sense). There are some clear examples of analogues of the judicial "inarticulate premise”.

Finally, ESA has generated considerable interest, both via its audio records and written data. Since 2011, Daniel Bates has placed the audio records in the Faculty's i-tunes service, and up to June 2013 these have received 34500 hits emanating from 127 countries, the most numerous being USA ( 15000), UK ( 11000) and Holland ( 3000).

\title{
Acknowledgements
}

The Eminent Scholars Archive would not exist without the co-operation, often after initial scepticism, of my interviewees. I thank them all for their forbearance, good humour, and tolerance of my prying into their careers and early lives. Also in some instances I have to thank their wives for hospitality and/or assistance.

I owe a great debt of gratitude to my colleague Daniel Bates for his continued vision, foresight, and technical assistance, and without whom the ESA website would not have become a reality. Matt Martin's enthusiastic support in the early years is also gratefully acknowledged. Finally, but not least, I thank David Wills, Librarian of the Squire Law Library for his moral and financial support, and generous encouragement of my ESA activities over the years.

\author{
References. \\ Allott, P. J. Eunomia, New Order for a New World, OUP ( 1990) pp. 427
}

${ }^{40}$ Lipstein, Dias, Bowett, Stein, Hepple, Lauterpacht, Schwebel, Koskenniemi, Auld, Jolowicz, Milsom, Finn, Stapleton, Prichard, Cane, Allott, Sealy, Flogaitis. Yet to be added to the website are Zines and Lady Jennings. 
Bagnall, W. S.. The Women’s Oral History Project at Columbia Law School (2001) Columbia Journal of Gender and Law, 10 (2), 163-166.

Baker, J. H. 750 Years of Law at Cambridge: a Brief History of the Faculty of Law, Faculty of Law, University of Cambridge (1996) 24pp.

Beatson, J. \& Zimmermann, R. Jurists Uprooted: German-Speaking Emigré Lawyers in Twentieth Century Britain, OUP( 2004) pp. 850

Brophy, P. The Library in the Twenty-first Century, $2^{\text {nd }}$ Edit, Facet Publishing, (2007) 248pp.

Charlton, T. L., Myers, L. E. \& Sharpless, R. (Eds), Handbook of Oral History, Altamira Press, (2006) pp 625.

Dingle, L. M. \& Bates, D. Conversations with Kurt Lipstein, Emeritus Professor of Comparative Law: some reminiscences over seventy years of the Squire Law Library and the Faculty of Law. International Journal of Legal Information, 35 (1), (2007) 93-133.

Dingle, L. M. 2008. Book Review: Brophy, P. 2007. The Library in the Twenty-first Century. Library Information Management, (2008) 7 (4), 151-152.

Elton, G. R. F. W. Maitland Yale University Press, (1985) pp. 118

Fenster, M. The folklore of legal biography (2007). Book review: Waller, S. W. Thurman Arnold: A Biography, New York, New York University Press, (2005) 273pp. Michigan Law Review, 105, 1265-1282.

Fisch, M. \& S Schaffer, S. (Eds.) William Whewell : A Composite Portrait. Clarendon Press, ( 1991) pp 403

Grele, R. J. Oral history as evidence. In: Charlton, T. L., Myers, L. E. \& Sharpless, R. (Eds), Handbook of Oral History, Altamira Press, (2006) 43-101.

Ibbetson, D. Historical research in law. In: Cane, P. \& Tushnet, M. (Eds), The Oxford Handbook of Legal Studies, OUP, (2003) 863-879.

Ibbetson, D. Publication Review: "A Natural History of the Common Law" S. F. C. Milsom, Columbia University Press, Law Quarterly Review, 120; ( 2004) 696-700.

MacQueen, H. Book review: A Guide to Oral History and the Law (2010) J. A. Neuenschwander 2009.

McEldowney, J. Challenges in legal bibliography: the role of biography in legal history. Irish Jurist, (2004 )215-242.

Meade, J. C. Talking Points: GW Law’s Oral History Project. A Legal Miscellanea, Newsletter of the Friends of the Jacob Burns Law Library vol. 1 , (2012) p. 1 \& 15.

Neuenschwander, J. A. A Guide to Oral History and the Law, Oxford, OUP, (2009) 167pp.

O’Farrell, P. Oral history: facts and fiction. Quadrant, (November), ( 1979) 3-9.

Oldfather, C. M. 2010. Oral history and the study of the judiciary. Book review: Domnarski, W. 2008. Federal Judges Revealed, OUP (2010) 240pp.

Parry, R. G. Is legal biography really legal scholarship? Legal Studies, 30 (2), (2010) 208229.

Prest, W. History and biography, legal and otherwise. Adelaide Law Review, 32, (2011) 185203.

Raisch, M. J. Shaping electronic collections in foreign, comparative and international law. In: Danner, R. A. \& Winterton, J. (eds), The IALL International Handbook of Legal Information Management, Farnham, Ashgate Publishing, (2011) 263-280.

Ritchie, D. J. Introduction: the evolution of oral history. In Ritchie, D. A. (Ed), The Oxford Handbook of Oral History, OUP, (2011) 3-19.

Simpson, A. W. B. Leading Cases in the Common Law, Clarendon Press, (1995)311pp.

Thomson, A. Memory and remembering oral history. In: Ritchie, D. A. (Ed), The Oxford 
Handbook of Oral History, OUP, (2011) 77-95.

Tilley, L, Peoples' history and social history, International Journal of Oral History, 6 (1),(1958) 5-18.
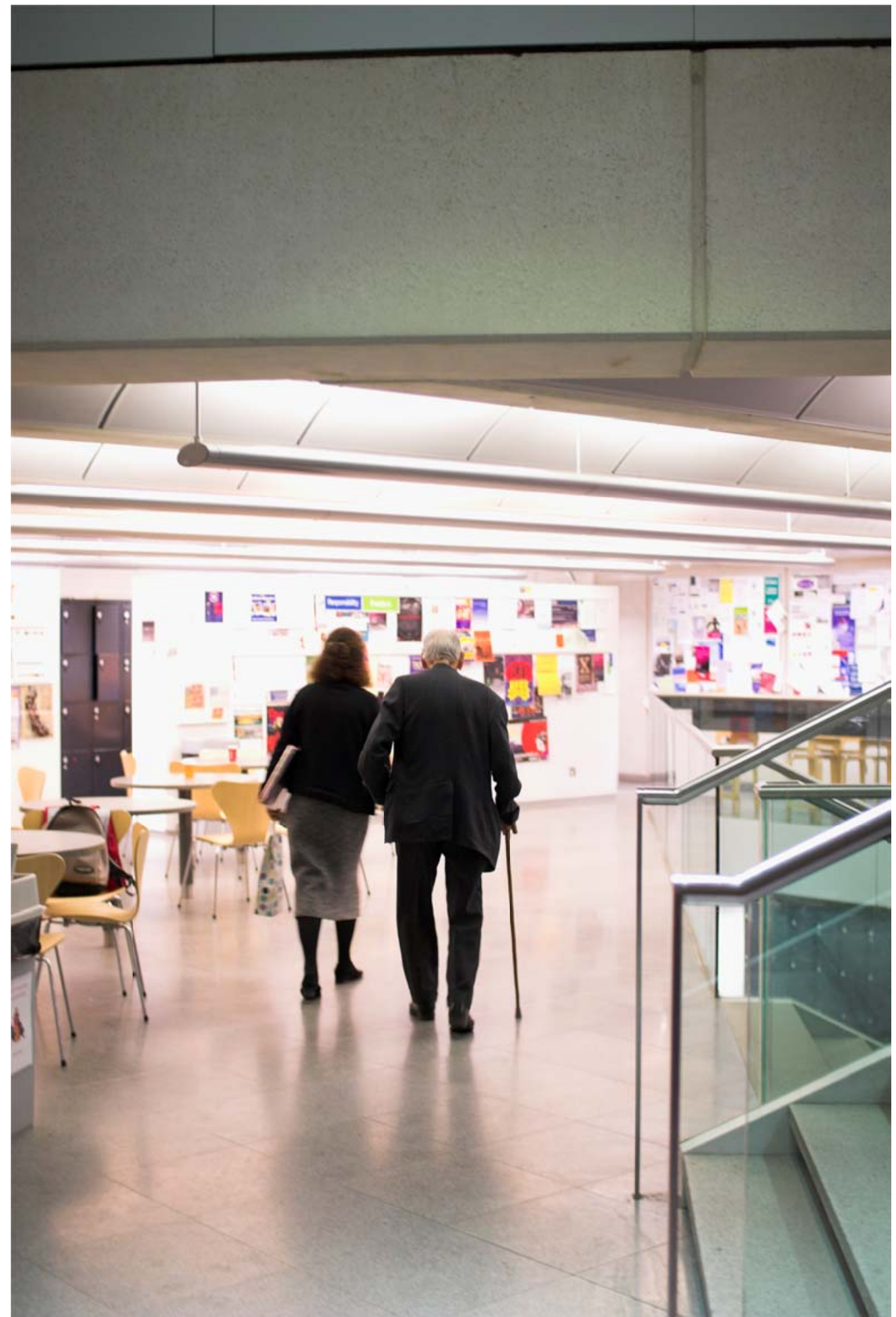

Fig. 1: End of the celebration in the Law Faculty for the 70th anniversary of Professor Kurt Lipstein's PhD. 20 November 2006. 


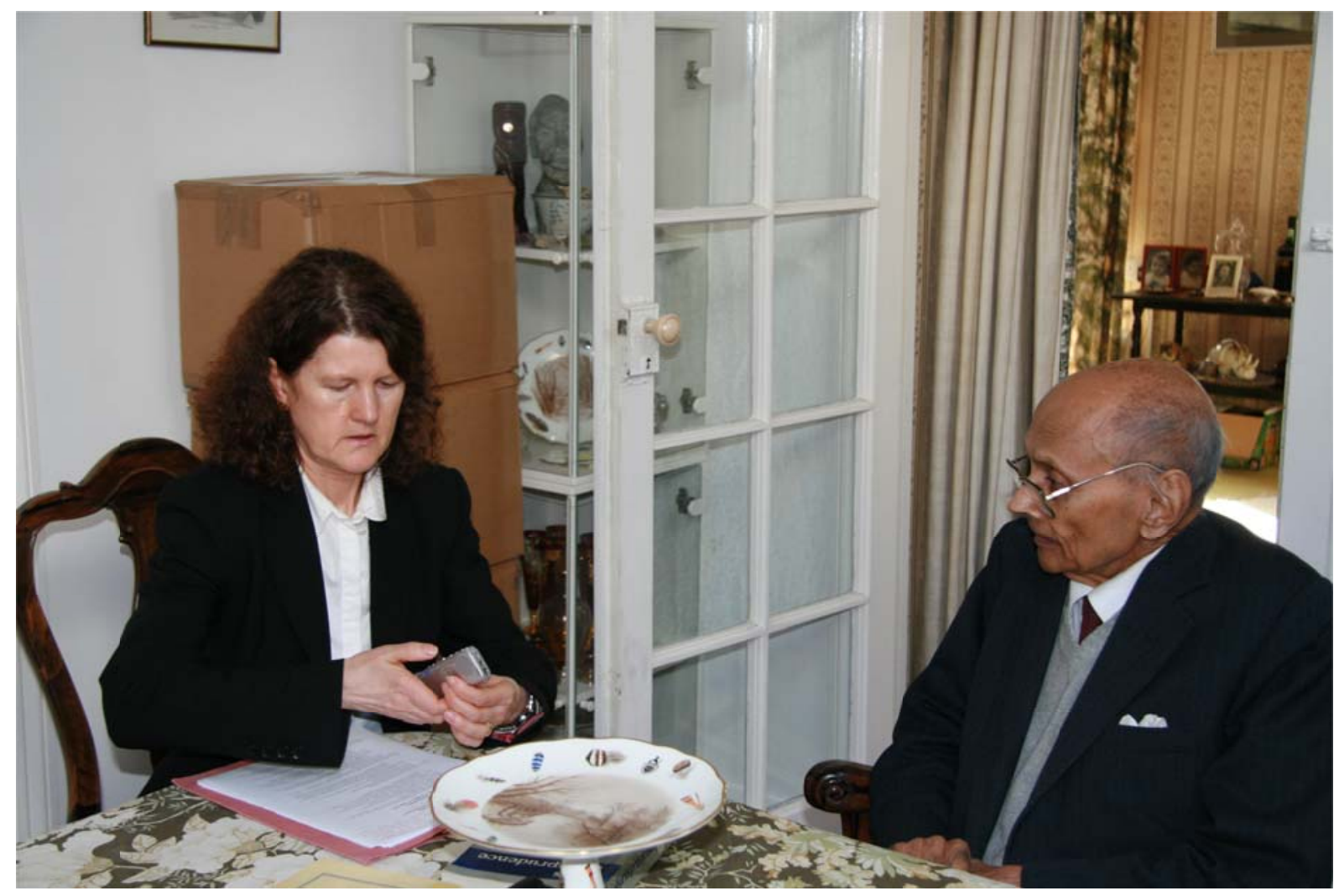

Fig. 2: Interviewing Mr R.W.M. Dias at his home on 17 January 2007.

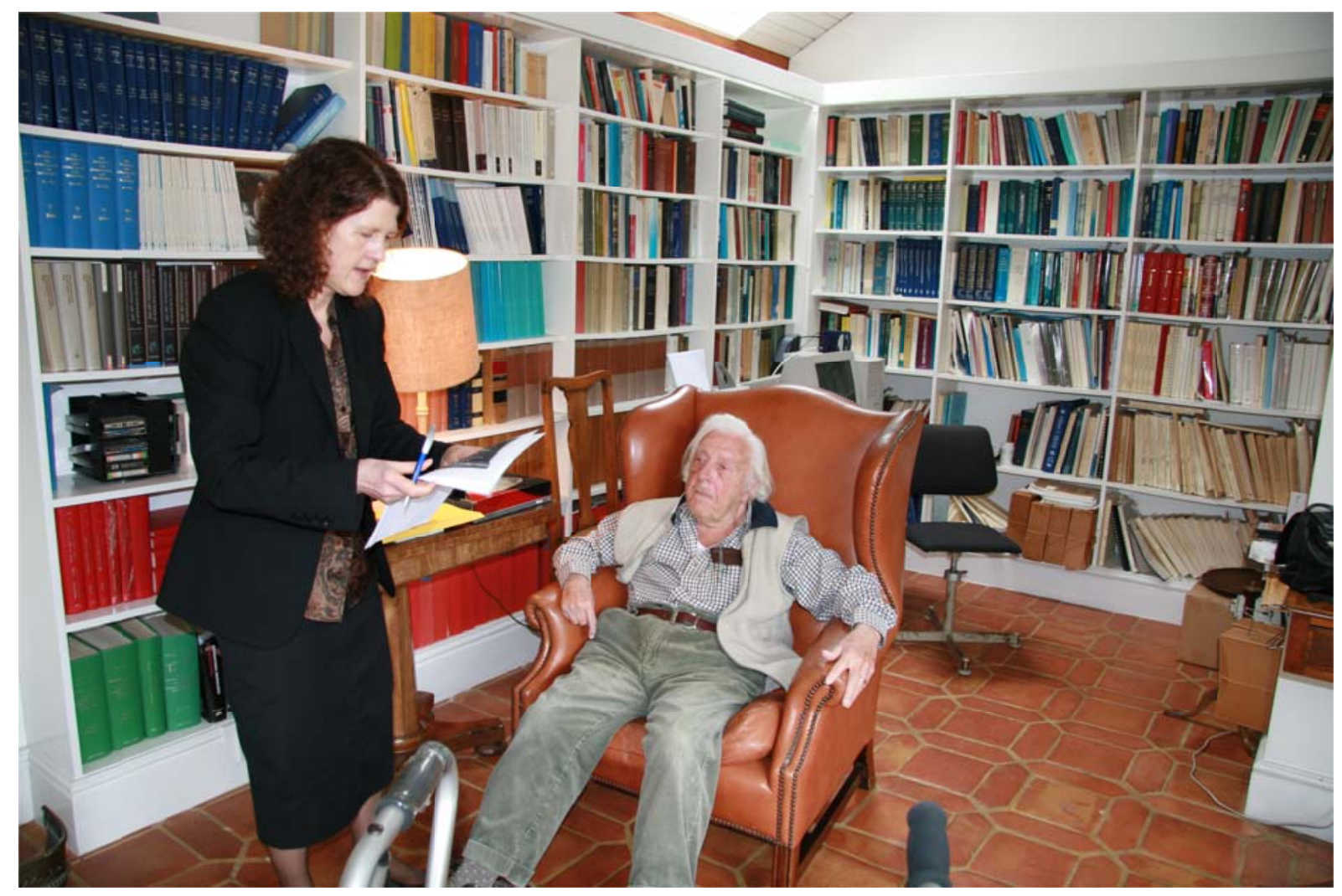

Fig. 3: Interviewing Sir Derek Bowett at his home on 16 March 2007. 